\title{
Putting supply chain learning into practice
}

John Bessant

Raphael Kaplinsky

CENTRIM, University of Brighton

Falmer, Brighton, BN19PH

Tel: 01273-642194

Fax: 01273-685896
Richard Lamming

CRiSPS

University of Bath

Claverton Down, Bath

Key words: Supply chain, learning, continuous improvement

\begin{abstract}
As firms struggle to cope with an increasingly turbulent and uncertain environment there is widespread recognition of the importance of organisational learning. One option here is to look at the potential of shared learning between firms, where common interests and interdependence provide motivation for experience-sharing and other forms of synergy in learning. A particular version of inter-firm learning is the use of supply chains as a mechanism for upgrading and transferring 'best practice' and this paper reports on exploratory research on this theme. It draws on a literature survey and a detailed study of six supply chains at various stages of implementing supply chain learning.
\end{abstract}

\section{Introduction}

Manufacturing is no longer simply a business of transformation of inputs into outputs through the use of standard equipment and techniques. Rather, as the recent White Paper on UK Competitiveness has pointed out, sustainable growth depends on the ability to master the knowledge content in production and this can only be achieved by developing the capacity to learn along the whole spectrum of economic activities. Best-practice is thus not a one-off "hit", but rather building up the capacity to change.

This places considerable emphasis on the ability of the firm to and to continue to learn to keep pace with an environment filled with competitive threats and new technological opportunities. However, the challenge does not stop at the boundaries of the firm. It is also becoming clear that many firms operate within value streams involving many firms in a supply chain or network and the competitive performance of this value stream depends upon learning and the development of the whole system, not just the leading players.

One approach which offers potential as a mechanism to enable learning and competence development is the supply chain, and this paper explores the extent to which this could become a viable approach within the UK. There are several good reasons for believing this might represent a vehicle for effective transfer, including the following:

口 there is a commonality of interest, focused on delivering value to a particular customer, and improvement of this core process along a supply chain 
- as a consequence of an increasingly competitive global environment, there is (potentially) a growing motivation to learn

a there are potential benefits to sharing the learning experience, including risk reduction, transfer of ideas, shared experiment, etc.

But, as a recent UK government report indicates, 'learning is not a natural feature of business networks. It is unlikely to thrive unless it is part of the emergent new models for inter-company collaboration which stress trust, co-operation and mutual dependence' (2000).

\section{The learning problem}

Research suggests that there are two important components involved in such learning; the first involves the accumulation and development of a core knowledge base - the 'core competence' which differentiates the firm from others and offers the potential for competitive advantage. Acquiring this is not simply a matter of purchasing or trading knowledge assets but the systematic and purposive learning and construction of a knowledge base. (Prahalad and Hamel 1994; Teece 1998)

The second is the long-term development of a capability for learning and continuous improvement across the whole organisation. Recognition of this need has led to growing emphasis on the concept of 'learning organisations' and on the mechanisms through which this capability can be developed (Cohen and Levinthal 1990; Garvin 1993; Bowen, Clark et al. 1994; Leonard-Barton 1995; Senge 1999). These include intra-firm processes, and those which involve relationships between firms - for example, in the context of supply chains. (Hines 1994; Dyer and Nobeoka 2000)

Learning in organisations is not automatic and there are a number of points at which learning fails to happen unless a blockage is dealt with. Such difficulties have led to exploration of mechanisms and structures which can support or facilitate learning - and one of these is the idea of inter-firm shared learning (Bessant and Tsekouras 2000). The potential benefits of such learning include mutual support, risk reduction through shared experimentation, exposure to different perspectives and challenging reflection on progress (Dent 2001).

\section{Supply chains as an option for enabling learning}

In considering the potential for supply chain learning we need to recognise the different components which make up apparent 'best practice' and which might be transferred via this mechanism. These range from relatively simple, incremental additions to a current knowledge set - for example, new regulations - through to complex new approaches which will involve experiment and adaptation. Work by the Tavistock Institute (Holti and Whittle 1998) examining 'learning networks' in the construction industry suggest a distinction between 'operational learning' and 'strategic learning'.

In similar fashion we need to recognise that there are different modes in which supply chain learning can be enabled. At one level it can involve a one-to-one relationship between two players in a chain - for example, a customer and a key supplier. At the other end of the spectrum 
from such dyadic relationships are multi-firm groupings - clusters or networks - where there is some element of shared learning - for example, a supplier club involving all or a large proportion of suppliers to a particular firm. In between we might have gradations - for example, into levels of multi-firm involvement (such as a customer firm working with a group of two or three suppliers to develop a new way of working. An example of this is provided by Guinness, who developed their 'real-time supply techniques, working with a bottle producer, label manufacturer and packaging suppliers).

\section{Research base}

In order to explore the issue of SCL and its potential for facilitating learning we carried out a two-phase research project on behalf of the UK Department of Trade and Industry. (The partners for this were CENTRIM, CRiSPS and IBM Consulting). Phase 1 involved a literature survey and selected interviews to review experience worldwide with SCL and phase 2 extended this work with further 'expert' interviews, a telephone survey of 25 organisations and detailed case studies of six supply chains. Our selection of these was driven partly by a view that they represented relatively advanced sectors in terms of supplier relationship development activities and in many cases had some explicit sector-wide programmes operating to foster SCL - for example, SCRIA in aerospace and CRINE and its successor programmes in the oil and gas industry. (Kaplinsky, Bessant et al. 1999; UKOGI 1999)

The six value chains chosen for detailed investigation represented different types of value chains, and encompassed a range of sectors and different types of firms. The chains were:

- Semiconductor industry equipment

- The production of tubular structures for the oil and gas industry

- The computing equipment industry

- Two different chains in the chemicals industry

- The aerospace industry

In addition, a workshop was held in London involving the participation of a number of public and private sector stakeholders and interviews were held with senior executives in the brewing, confectionery, the Northern Ireland aerospace industry and the surface finishing sectors.

\section{A model of supply chain learning}

In order to analyse our empirical data we have used a model of supply chain learning which suggests a number of generally sequential steps. This is an 'ideal type' model and involves the following stages (Table 1), usually (but not always) completed in a series of sequential steps:

Table 1: Steps in the Evolution of Supply Chain Learning

1. A "wake up call", with the drivers varying in different sectors and in different parts of the world

2. The adoption of new organisational procedures within firms in response to this wake-up call (mainly in the quality and materials management areas) 
3. These internal changes are soon recognised to be of limited effectiveness unless the supply chain (and indeed the customer base) simultaneously undergoes complementary changes

4. The rationalisation of the vendor base (or the customer base), so that these complementary changes can more easily be implemented and synchronised

5. The communication to vendors (and customers) of the new requirements which changing market conditions require

6. Mandating change in behaviour among suppliers (and customers)

7. Assisting suppliers (and customers) to achieve these new performance levels in their own activities in the design of a SCL programme, its running and in sustaining it over time

8. Assisting suppliers (and customers) to aid their own suppliers (and customers) in similar processes of change in the various tiers of the chain

9. Developing the ability to learn from suppliers and customers, not just to teach them

It can readily be seen from this that SCL (the transfer of 'best practice' through the supply chain) is only part of a wider process of change as firms adjust to the pressures of international competition. Similarly, in proceeding through these (generally sequential) stages, a key break occurs at Stage 7: it is here that SCL, generally involving active coordination by one or more key links in the chain, truly begins

From the research it appears that there are three distinct phases in the development of SCL - setup, running (i.e. the operation of the SCL programme) and long-term sustaining. The first set-up phase involves the establishment of a set of procedures to promote SCL. However, once these procedures have been established - the 'running phase' - the challenge then is to ensure that they are translated into a set of routines and norms which govern the behaviour between and within firms, and this forms the basis of the second phase.

The problem is that once these routines and norms have been established - often involving changing behaviour by individuals and firms - there is a natural tendency for behaviour to return to traditional patterns. Therefore, a third and important stage in SCL involves the ability to sustain these activities, and not to allow them to degrade and lose impetus.

\section{Results}

Despite our selection of case studies from what are generally regarded as relatively advanced sectors (in terms of supply chain development activity) it can be seen from Table 2 that most supply chain management programmes do not yet incorporate SCL. Where SCL does occur, it is mostly limited to the first tier suppliers (or customers), and very seldom involves structured processes of learning from suppliers (or customers). If these relatively progressive chains have not yet systematically addressed the challenge of SCL, then there is clearly much opportunity for improvement in the UK economy. It may be worth adding that those companies that are trying to expand the SCL further down the chain are finding this task difficult.

. Table 2: The Extent of SCL in the Six Value Chains: 


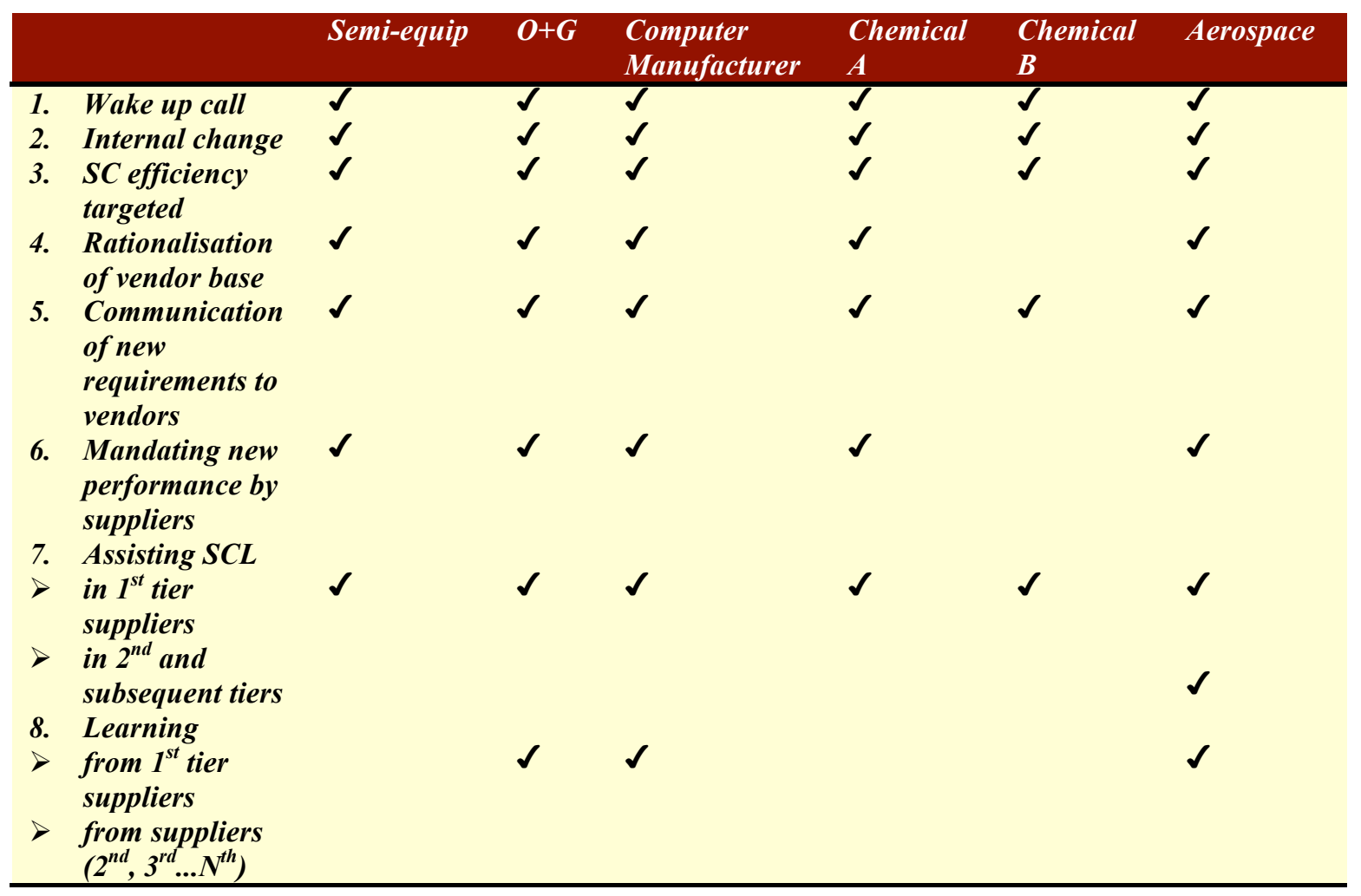

\section{Diffusion, drivers and the extent of development}

Despite the potential offered by SCL, diffusion has been limited. In most cases, supply chain development has effectively only reached the stage of mandating performance improvement rather than in assisting change within suppliers. In those cases where SCL programmes have been put in motion, the pace of change has been steady rather than dramatic.

For example, in the case of equipment for the semiconductor industry, although the key supply chain co-ordinator firm (SCC) began working in the early 1990s, change is predominantly still only occurring in the first tier. The second and third tiers are only beginning a process of change, and indeed the drivers to change at this level of the chain come as much from below as they do from above. Moreover, the changes, which are occurring, are predominantly limited to improvements in logistics, and even then some of this involves an increase rather than decrease in total inventories (with the major rewards being experienced in security and reliability of delivery).

In contrast however, the aerospace example shows that indeed the focus is still based around first tier suppliers but the changes brought about within these suppliers are owned by the suppliers and are not mandated. The suppliers own the continuous improvement plan that is jointly developed with the SCC and the sole responsibility for selection and implementation of improvement remains with the supplier. 
There are a number of factors driving the introduction of SCL. For example in the case of semiconductor equipment, the primary drivers at to the onset of change were technological in nature, involving a fundamental change in the design of the equipment. However, these technological imperatives were complemented initially by sustained pressure on pricing and then on the ability to satisfy wildly fluctuating volumes of production. The major driver towards SCL from the mid-1990s has been to assure reliable suppliers of components to counter fluctuations in demand (which can be up to 70 per cent on a month-to-month basis).

\section{Set up, Running and Sustaining SCL}

Table 3 highlights examples from the case firms on how these firms set up, ran and sustained their SCL programmes.

Table 3: Implementing SCL Programmes in the Six Value Chains

\begin{tabular}{|c|c|c|c|c|}
\hline & SCL Driver & Setting up & Running & Sustaining \\
\hline Semi- equip & $\begin{array}{l}\text { Improving } \\
\text { supplier quality }\end{array}$ & $\begin{array}{l}\text { The pilot scheme } \\
\text { began with local firms } \\
\text { and with suppliers } \\
\text { with a high transaction } \\
\text { cost }\end{array}$ & $\begin{array}{l}\text { Teams were set up } \\
\text { with equal numbers } \\
\text { from Semi-equip and } \\
\text { supplier. Teams set } \\
\text { joint targets and hold } \\
\text { regular reviews. }\end{array}$ & $\begin{array}{l}\text { The supply chain } \\
\text { programme is not } \\
\text { focusing proactively on } \\
\text { SCL }\end{array}$ \\
\hline$O+G$ & $\begin{array}{l}\text { Comprehensive } \\
\text { supply } \\
\text { management }\end{array}$ & $\begin{array}{l}\text { The programme set out } \\
\text { to establish long term } \\
\text { contracts with } \\
\text { contractors } \\
\text { Best practices were } \\
\text { process oriented and } \\
\text { directed at the } \\
\text { relationship between } \\
\text { the customer and } \\
\text { suppliers }\end{array}$ & $\begin{array}{l}\text { Commitment to share } \\
\text { information } \\
\text { Close collaboration } \\
\text { between the SCC and } \\
\text { its contractors. } \\
\text { Setting up co- } \\
\text { operative schemes to } \\
\text { improve the entire } \\
\text { supply chain. } \\
\text { Measurement systems } \\
\text { captured visible } \\
\text { results such as cost } \\
\text { savings }\end{array}$ & $\begin{array}{l}\text { Annual reviews of } \\
\text { supplier performance and } \\
\text { assessing management } \\
\text { practices. }\end{array}$ \\
\hline
\end{tabular}




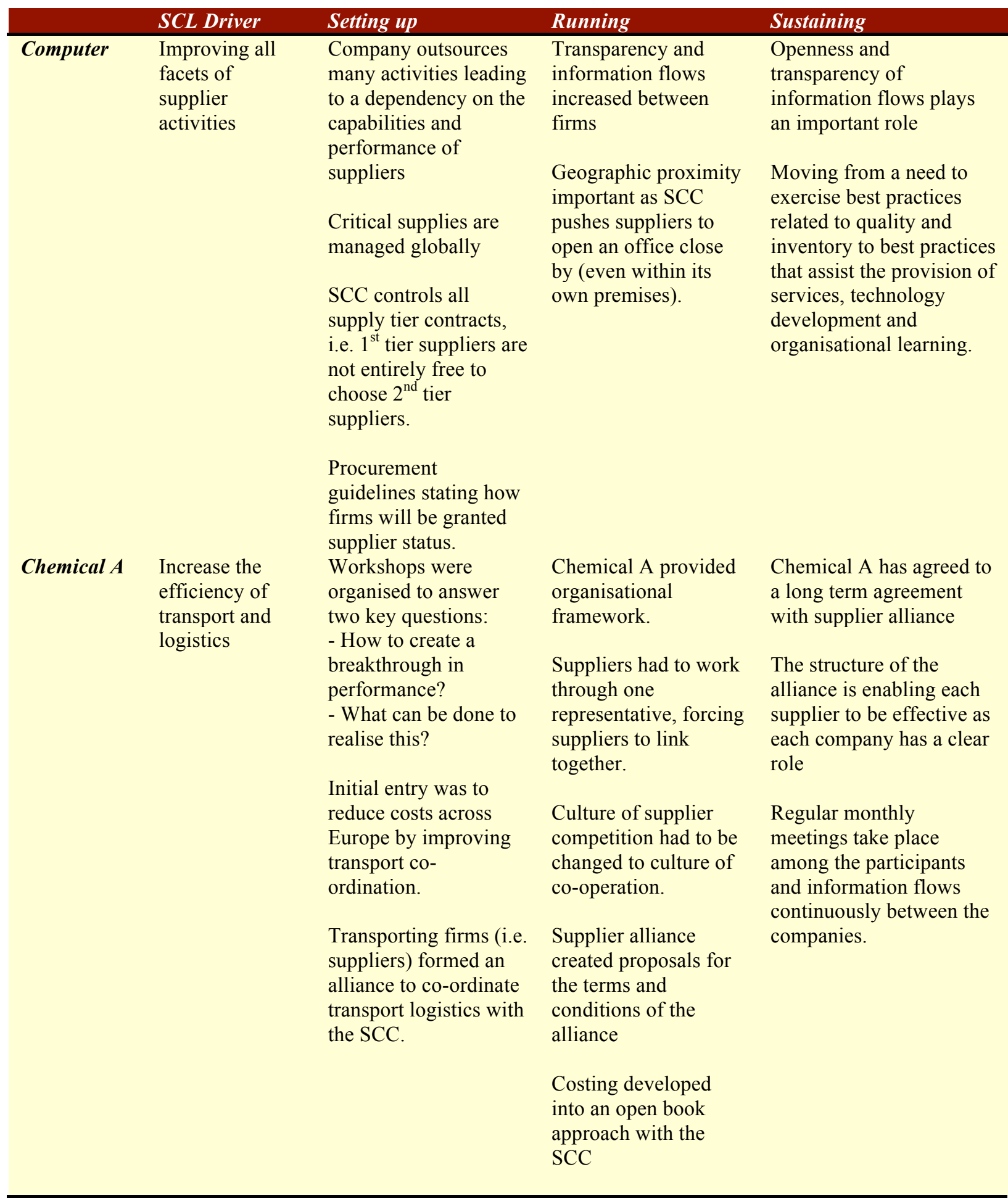




\begin{tabular}{|c|c|c|c|c|}
\hline & SCL Driver & Setting up & Running & Sustaining \\
\hline Chemical B & $\begin{array}{l}\text { Reducing } \\
\text { inventories \& } \\
\text { improving } \\
\text { interfaces } \\
\text { throughout the } \\
\text { supply chain }\end{array}$ & $\begin{array}{l}\text { External assistance } \\
\text { from a consulting body } \\
\text { was sought for supply } \\
\text { chain models } \\
\text { Reviewed total global } \\
\text { inventory. How to } \\
\text { reduce the total level } \\
\text { of inventory for } \\
\text { everyone in the chain? } \\
\text { Inventory was reduced } \\
\text { gradually with greater } \\
\text { reductions occurring as } \\
\text { customer confidence } \\
\text { grew. }\end{array}$ & $\begin{array}{l}\text { Chemical B used an } \\
\text { open book approach. } \\
\text { to counter concerns } \\
\text { about losing the } \\
\text { security of holding } \\
\text { large inventories }\end{array}$ & $\begin{array}{l}\text { Improvement projects } \\
\text { were used with defined } \\
\text { measures and objectives. } \\
\text { Upon completion, new } \\
\text { projects were built on the } \\
\text { previous project results } \\
\text { but alignment with new } \\
\text { business unit objectives } \\
\text { was ascertained. }\end{array}$ \\
\hline Aerospace & $\begin{array}{l}\text { Improving } \\
\text { quality, delivery } \\
\text { performance and } \\
\text { responsiveness } \\
\text { of suppliers }\end{array}$ & $\begin{array}{l}\text { Aerospace adapted the } \\
\text { approach used in a } \\
\text { previous collaboration } \\
\text { and adopted it to their } \\
\text { suppliers. } \\
\text { Senior management } \\
\text { commitment key as the } \\
\text { programme required } \\
\text { significant resources. }\end{array}$ & $\begin{array}{l}\text { Suppliers undertake } \\
\text { self-assessment. } \\
\text { Aerospace also } \\
\text { performs a detailed } \\
\text { assessment. Results } \\
\text { fed into a continuous } \\
\text { improvement plan } \\
\text { created by supplier, } \\
\text { which is monitored by } \\
\text { Aerospace over time. } \\
\text { Free assessments and } \\
\text { training for suppliers. } \\
\text { Exposure visits by } \\
\text { supplier staff to other } \\
\text { firms also arranged. } \\
\\
\text { Suppliers have the } \\
\text { opportunity to } \\
\text { improve their } \\
\text { business, and develop } \\
\text { a long-term } \\
\text { relationship. }\end{array}$ & $\begin{array}{l}\text { Programme has changed } \\
\text { over time and now looks } \\
\text { to incorporate functions } \\
\text { such as finance and } \\
\text { human resource } \\
\text { development } \\
\text { Difficult to get } 2^{\text {nd }} \text { and } 3^{\text {rd }} \\
\text { tier suppliers into the } \\
\text { programme. } \\
\text { Programme re-launched } \\
\text { to ensure current } \\
\text { relevance and generate } \\
\text { increased interest }\end{array}$ \\
\hline
\end{tabular}

\section{Learning in the Supply Chain cases}

Our results indicate that learning has not cascaded throughout the supply chain. Most cases reported some learning by the $1^{\text {st }}$ tier supplier from the lead firm, and even a case of the coordinating firm learning from a $1^{\text {st }}$ tier supplier. However, further along the supply chain, learning activities among suppliers and customers is more limited. The control of the co-ordinating firm is not so strong at the $2^{\text {nd }}$ and $3^{\text {rd }}$ tiers (except in the case of the computer manufacturer). Table 4 highlights several learning points we found in the case studies. 
Table 4: Learning Points in the Six Value Chains

Supply Chain Learning

Semi- Equip Evidence of the development of learning capabilities in one of the first-tier suppliers.

Problem solving techniques were used by suppliers forming teams together with staff from the customers. But, in important respects, the SCC is itself a poor role model and learning is thus limited within the first tier

$\boldsymbol{O}+\boldsymbol{G} \quad$ Constant dialog between the customer and the suppliers has led to better understanding among all parties. Day-to-day work activities generate issues which are then incorporated into the strategic issues.

Supply chain issues are moving from practices related to material management toward soft ones such as services.

Supplier recognise that a two-way learning process has occurred with a) SCC adopting some of the suppliers techniques and 'b) the supplier taking on practices first used by the SCC.

Computer The SCC establishes a set of standardised evaluations that are applicable to all suppliers. This tool is used to benchmark all suppliers providing similar inputs. The results are communicated to all suppliers This practice gives clear advantage to the SCC during the bargaining processes.

No system implemented to measure the performance of the entire chain.

Creation of the supplier alliance improved relationship between all the suppliers and the chemical company enabling improved information transfer and understanding of requirements.

Chemical A Supplier alliance may prove to have a long-term benefit to suppliers (too early to determine).

The concept of a supplier alliance is very useful in the transportation industry and there are prospects of transferring the initiative within the industry.

Chemical B Customer introduced 6 sigma SPC into SCC's manufacturing plants. This was not a structured mechanism of transferring best practice but a one-off occurrence.

Chemical B does not want to be responsible for passing initiatives beyond their direct customers or $1^{\text {st }}$ tier suppliers.

Aerospace The business assessments highlights areas for improvements and suggested tools and techniques that can be used to satisfy these requirements. Suppliers were able to implement changes.

Some suppliers have transferred the Business Assessment into a Continuous Improvement Plan. The supplier takes ownership of the plan and is responsible for delivery.

Suppliers have not taken a consistent approach towards disseminating tools and techniques or lessons learnt to their own suppliers and do not feel responsible for dissemination to their second and third tier suppliers 


\section{Have Companies benefited from SCL?}

Table 5 lists several of the benefits firms realised from the SCL programmes, confirming that SCL programmes can be win-win programmes.

Table 5: Sample Benefits Realised from SCL in the Six Value Chains

\begin{tabular}{|c|c|c|c|c|c|c|}
\hline & & Benefits to SCC & & Benefits to first-tier & & Benefits to second \\
\hline Semi-equip & ם & $\begin{array}{l}\text { Sales quadrupled over } 10 \\
\text { years } \\
\text { Incoming deliveries in } \\
\text { kanbans: increased from } \\
30 \% \text { to } 80 \% \text { in } 3 \text { years }\end{array}$ & ם & $\begin{array}{l}\text { On time delivery: } \\
87 \%(1997)-100 \% \\
(1998) \\
\text { Scrap (internal and } \\
\text { external): } 1.5 \% \\
(1995)-0.15 \% \\
(1999) \\
\text { Stockturns: } 20 \\
(1995)-40(1999) \\
\text { Set up time as \% } \\
\text { production time: } \\
>15 \%(1995)-10 \% \\
(1999)\end{array}$ & $\begin{array}{l}\square \\
\square \\
\square\end{array}$ & $\begin{array}{l}\text { Sales: grown } 29 \% \\
\text { since } 1995 \\
\text { Stockturns: } 8.5 \\
\text { (1996)- } 10.7 \text { (1998) } \\
\text { Lead time: weekly } \\
\text { (1996) - next day } \\
\text { delivery (1999) }\end{array}$ \\
\hline$O+G$ & $\square$ & $\begin{array}{l}\text { The adoption of best } \\
\text { practices through the } \\
\text { supply chain may have } \\
\text { generated saving of } £ 1 \\
\text { billion }\end{array}$ & 口 & $\begin{array}{l}\text { First tier supplier } \\
\text { benefited as it saved } \\
5 \% \text { of total costs. }\end{array}$ & $\square$ & $\begin{array}{l}1^{\text {st }} \text { tier supplier helped } \\
\text { the } 2^{\text {nd }} \text { tier supplier cut } \\
\text { down lead-time from } \\
14 \text { weeks to only } 16 \\
\text { days. }\end{array}$ \\
\hline Computer & $\begin{array}{l}\square \\
\square\end{array}$ & $\begin{array}{l}\text { Cost reductions. } \\
\text { Reduction of the number of } \\
\text { first tier suppliers from } \\
\text { around } 1,000 \text { to nearly } 200 \text {. } \\
\text { Reduced the time to market } \\
\text { and increased profit } \\
\text { margins and revenues. }\end{array}$ & & & 口 & $\begin{array}{l}2^{\text {nd }} \text { tier supplier now } \\
\text { concentrates on } \\
\text { technological } \\
\text { capabilities which has } \\
\text { increased the profit } \\
\text { margins of the } \\
\text { company. }\end{array}$ \\
\hline Chemical A & 口 & $\begin{array}{l}\text { The alliance has achieved } \\
\text { total savings of } 6 \% \text {, which } \\
\text { was jointly shared by the } \\
\text { alliance and Chemical A. } \\
\text { Productivity has grown by } \\
4-5 \% \text {. }\end{array}$ & 口 & $\begin{array}{l}\text { Suppliers now have } \\
\text { access to better } \\
\text { equipment while all } \\
\text { drivers are trained in } \\
\text { defensive driving }\end{array}$ & $\square$ & N/A \\
\hline Chemical B & $\square$ & $\begin{array}{l}\text { Quality and delivery time } \\
\text { of materials has improved } \\
\text { leading to cost savings } \\
\text { throughout the supply } \\
\text { chain. }\end{array}$ & $\square$ & $\begin{array}{l}\text { Customers reduced } \\
\text { inventory and in } \\
\text { other targeted areas. }\end{array}$ & 口 & \\
\hline Aerospace & 口 & $\begin{array}{l}\text { Quality and delivery time } \\
\text { of materials has improved } \\
\text { leading to cost savings } \\
\text { throughout the supply chain }\end{array}$ & $\square$ & $\begin{array}{l}\text { Improved processes } \\
\text { and reduced interface } \\
\text { issues leading to } \\
\text { delivery, quality and }\end{array}$ & $\square$ & $\begin{array}{l}\text { Use of SPC } \\
\text { techniques to improve } \\
\text { quality }\end{array}$ \\
\hline
\end{tabular}


and relationships between participating companies has been enhanced. responsiveness

improvements.

\section{Factors helping and hindering the development of SCL.}

Table 6 below summarises specific blocks and enablers to the development of SCL for each of the individual chains.

Table 6: Blocks and enablers to SCL

Chain

Semi-

Equip

$\boldsymbol{O}+\boldsymbol{G}$

\section{Enablers to SCL}

口 Visits to the shop floor of customers and suppliers by production staff

a Joint teams, involving a combination of management and production staff from both plants

- Extensive communication by fax "faxbans" - and through the use of email, but no plans for the introduction of EDI proper.

a In general large firms are more difficult to influence than small firms, since they have lower degrees of dependence.

口 Proximate suppliers are much easier to work with.

․ Senior management commitment.

口 The existence of external bodies (e.g. CRINE) actively involved in the transmission of information on a collective and individual basis

口 Disposition to learn from suppliers

- Avoiding an over-prescriptive approach towards suppliers.

- Willingness to learn from experiences from different industries.

- Focus on other aspects apart from price to assess suppliers and to ensure the sustainability of supply chains.

- Commitment on the part of the SCC to learn from suppliers and to accept that some answers to the supplier's malpractice could be found in their own malpractice.

․ Development of high quality procurement areas

- Periodic revision of objectives and measurement systems.

a Practising open-book type of relationship with the suppliers.

\section{Blocks to SCL}

- The slow and inconsistent pace of change within Semi-equip and some of its first tier suppliers.

- Low levels of trust and the reluctance to become too dependent on suppliers/customers.

- A lack of systematic overview to the problems of supply chain learning.

- Absence of a proactive culture, both in relation to the broader problem of supply chain development, and the more specific challenges, which arise in promoting SCL.

․ Lack of right skills.

a Time constraint

a Incompatibility between what the SCL manager wants to promote and the objectives of particular parts of the company.

- Arrogance of some SCC managers

- Some of the results of SCL are not easy to identify and sometimes are attributed to other activities 
- High level of trust between the elements of the chain.

- Crystal clear objectives, methods of performance assessment and contracts.

- Uninterrupted flow of useful information.

․ Physical proximity

a Use of IT to communicate within and between firms.

- Suppliers linked to other SCL initiatives (networking).

- Helping the suppliers to "see the benefits of SCL all the time"

Chemical $\square$ "Trust, trust and trust" between all the A

Chemical B

Aerospace

The consideration that SCC is a major customer

- Skilled and dedicated resources within the SCC

- Structured approach, tools and techniques transferred

- Responsibility of the improvement plan lies with the company to which it relates

- Visibility of the results achieved through using the approach, tools and techniques

․ Consistency in measures across first tier
- Cultural differences between companies and within parts of the same company.

a Lack of processes to record the lessons obtained through SCL.

- External problems that impede the disclosure of information (e.g. legal procedures and poor protection of property rights in other countries).

- Failure to understand the problem and see joint benefits from all parties' points of view

口 Protecting own corner instead of looking for the bigger picture

- Failure to work with competitors

․ Failure to change culture, both within the SCC and other firms in the supply chain a People protecting their own corner of the company and not having the vision to see the company benefits.

- Not being involved in the change

- Slow project start-up leads to limited involvement and quick loss of interest

- Inability to trust other participants

口 Lack of willingness to become involved due to the perceived restriction of investing in only one supplier

- Multiple assessments due to different customer requirements

- Inadequate knowledge and skilled resource in suppliers

- Inadequate availability and consistency of SCC's support

- Inability to disseminate further than the first tier of suppliers

- The approach of searching for one-size-fitsall solutions

- Low cost culture of the aerospace industry creating destructive preconceptions 
suppliers enabling comparisons to be

made and awards to be given

- Assessments and participation in the programme and sharing of the tools and techniques was all free of charge and financial benefits generated were not all appropriated by the SCC

\section{Conclusions}

It is clear that continuous learning within and between organisations will be a key strategic requirement for building and sustaining future competitiveness. Experience from a variety of countries suggests that inter-firm learning (organised in various forms) can provide positive support for this process and yield beneficial results. But, as these case studies and the accompanying research show, progress towards achieving SCL is still at an early stage and being made with faltering steps. There is clearly a need for more research in the field and for more experimentation towards developing firm and sector-specific models. (There are signs that this is beginning to accelerate; the perceived success of initiatives like CRINE in the oil and gas sector, SCRIA in aerospace and the SMMT Industry Forum in the automotive components sector has led to a government-supported roll-out of such initiatives as part of the policies following the 1999 White Paper).

In conclusion we would highlight four themes which require more detailed analysis and development:

- The importance of implementing SCL on a platform of 'good practice' supplier management (and the need to review such programmes to add the SCL dimension)

- The concept of supply chain 'governance' and the roles which can be played by different actors in the SCL network

- The role of facilitation and the skill sets and enabling toolkit which permit effective learning networks of the kind reported here to evolve

- Processes through which a shared learning agenda (and related 'curriculum', assessment frameworks, etc.) can be developed. Early evidence suggests this needs to take place at a sector or supply chain level - for example, via business associations

\section{References}

(2000). Learning across business networks. London, Department of Trade and Industry. Bessant, J. and G. Tsekouras (2000). "Developing learning networks.” A.I. and Society forthcoming. 
Bowen, H., K. Clark, et al. (1994). "Regaining the lead in manufacturing." Harvard Business Review(September/October): 108-144.

Cohen, W. and D. Levinthal (1990). "Absorptive capacity: A new perspective on learning and innovation." Administrative Science Quarterly 35(1): 128-152.

Dent, R. (2001). Collective knowledge development, organisational learning and learning networks: an integrated framework. Swindon, Economic and Social Research Council.

Dyer, J. and K. Nobeoka (2000). "Creating and managing a high-performance knowledge-sharing network: The Toyota case.” Strategic Management Journal 21(3): 345-367.

Garvin, D. (1993). "Building a learning organisation.” Harvard Business Review July/August: 78-91.

Hines, P. (1994). Creating world class suppliers:Unlocking mutual competitive advantage. London, Pitman.

Holti, R. and S. Whittle (1998). Guide to developing effective learning networks in construction. London, CIRIA/Tavistock Institute of Human Relations.

Kaplinsky, R., J. Bessant, et al. (1999). Using supply chains to diffuse 'best practice'. Brighton, Centre for Research in Innovation Management.

Leonard-Barton, D. (1995). Wellsprings of knowledge: Building and sustaining the sources of innovation. Boston, Mass., Harvard Business School Press.

Prahalad, C. and G. Hamel (1994). Competing for the future. Boston, Mass., Harvard University Press.

Senge, P. (1999). The dance of change: Mastering the twelve challenges to change in a learning organisation. New York, Doubleday.

Teece, D. (1998). "Capturing value from knowledge assets: The new economy, markets for know-how, and intangible assets." California Management Review 40(3): 55-79.

UKOGI (1999). A template for change; The Oil and Gas Industry Task Force report. London, Department of Trade and Industry. 